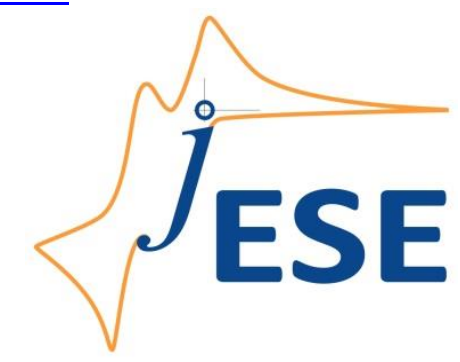

Open Access: ISSN 1847-9286

www.jESE-online.org

Original scientific paper

\title{
Remediation of clay soil contaminated with lead nitrate using washing-enhanced electrokinetic technique
}

\author{
Mahdi Karkush ${ }^{凶}$, Shahad Ali \\ College of Engineering, University of Baghdad, Iraq \\ ${ }^{\otimes}$ Corresponding author: E-mail mahdi karkush@coeng.uobaghdad.edu.iq; Tel.: +9647801058893
}

Received: July 23, 2018; Revised: October 8, 2018; Accepted: November 13, 2018

\begin{abstract}
The remediation of clay soil contaminated with lead nitrate has been investigated in details by using the electrokinetic technique enhanced by using purging solutions, mid compartment, and washing technique. The intact soil samples are obtained from Al-Ahdab oil field located in the southeast of Iraq. The soil samples are contaminated synthetically with two different percentages of lead nitrate $(6.67$ and $20 \mathrm{~g} / \mathrm{kg}$ ) and kept for 30 days. The mid compartment is used to reduce the existing paths of contaminants from the soil. Purging solutions in the anode, mid, and cathode compartments are used to control the $\mathrm{pH}$ value, while the activated carbon is used to prevent the reverse electroosmotic flow from cathode to anode. The main results of electrokinetic experiments, such as variations of electrical current and $\mathrm{pH}$ with time, and the accumulated volume of electroosmotic flow are presented and discussed. It was shown that increasing of the concentration of lead causes increase of the electrical current generated during the remediation process. As a consequence, the intensity of chemical reactions occurring in the anode, mid, and cathode compartments are also increased. The removal efficiency of lead from soil samples ranged between 12.4 and $21 \%$. The washing process is found beneficial in reducing the period of remediation but does not affect the removal efficiency.
\end{abstract}

\section{Keywords}

Heavy metals; lead; contaminated soil; soil remediation; washing; electrokinetic

\section{Introduction}

The contamination of soil is a significant problem that was increased in recent years because of development of industrial, agricultural, and military activities. Heavy metals (HMs) are considered as the major contaminants which have diverse effects on geotechnical properties of soil. The effects of contaminants depend on several factors such as their mobility and chemical activity in the soil, especially when the content of contaminants is above certain levels $[1,2]$. HMs usually adhere to the 
soil particles and thus become immobile. This process is called sorption and describes the distribution of HMs between the solid and pores solution. Contamination of soil with HMs causes reduction of shear strength parameters of soil. Also, contamination of soil with HMs leads to increased compressibility and maximum dry density, but decreased optimum moisture content and permeability of soil [1]. Costs and removal efficiency are the major factors in selection of the remediation technique for removing contaminants from the soil. Also, sites contaminated with more than one type of contaminants require more than one type of remediation technique that should be applied simultaneously or in a sequence. Generally, the process of removing HMs from the soil is considered difficult, because the metals are not biodegradable or soluble in water, except mercury and selenium which could degrade and volatilize by microorganisms. The electrokinetic method (EK) has already been found suitable for the remediation of low permeability contaminated soils through applying DC current between two electrodes installed in the medium. There are generally three phenomena occurring during the EK process: electroosmosis, electromigration and electrophoresis [3].

The removal efficiency of HMs from a soil depends on several factors such as the type and composition of HM in the soil matrix and the type of soil [4,5]. During the EK process, the electrolysis occurs at the electrodes, generating hydrogen ions at the anode and hydroxide ions at the cathode $[6,7]$. The hydrogen ions move from the anode toward cathode while hydroxide ions move from the cathode toward anode. The advance of the acid fronts is faster than advance of the basic front migration, because the mobility of $\mathrm{H}^{+}$is greater than $\mathrm{OH}^{-}$for about 1.76 times [8]. Only few studies, however, investigated effects of HMs on geotechnical properties of the soil. Li et al. [9] studied the removal efficiency of cadmium (II), lead (II), and chromium (III) from a sandy soil. They used a conductive solution to separate the soil and cathode compartments, in order to enhance the removal efficiency which can be higher than $90 \%$. Reddy and Chinthamreddy [4] studied the effects of different purging solutions on removal efficiency of $\mathrm{HMs}$ from the soil contaminated with different percentages of $\mathrm{Cr}, \mathrm{Ni}$, and $\mathrm{Cd}$. The removal efficiency of contaminants was found very low when the tap water was used as a purging solution, but increased when $1 \mathrm{M}$ of acetic acid and 0.1 $M$ of ethylene diamine tetraacetic acid were used as the purging solution in the cathode compartment. The maximum removal efficiency was obtained when water was used as a purging solution at the beginning of the test in anode and cathode compartments, being followed by using acetic acid as the purging solution in the cathode and $\mathrm{NaOH}$ solution in the anode compartments. Jensen et al. [10] demonstrated that soils with high content of carbonate compounds produced negative effects on the removal efficiency of lead from the soil. Karkush and Altaher [7] studied the remediation of the clayey soil contaminated with several concentrations of total petroleum hydrocarbons by using washing-enhanced electrokinetic technique. The purging solution used to enhance EK consisted of $30 \%$ of ethanol and $70 \%$ of deionized water. The results of tests demonstrated the removal efficiency of $15 \%$ after 10 days of remediation.

In the present study, the washing-enhanced EK technique was used in the remediation of a finegrained soil contaminated with two different percentages of lead nitrate. The EK technique was enhanced by using purging solutions and the mid compartment to increase the removal efficiency of lead from soil. Also, the activated carbon was used to prevent the reverse electroosmotic flow.

\section{Experimental}

\section{Soil sampling and materials}

The intact soil samples were obtained from an open pit excavated to a depth of $3 \mathrm{~m}$ below the existing ground level (EGL) in the site of Al-Ahdab oil field located in the southeast of Iraq. Depending 
on the unified soil classification system (USCS), the intact soil was classified as silty clay of high plasticity $(\mathrm{CH})$. The fine-grained soil is highly affected by contaminants, due to its large specific surface area, dynamic crystalline structure and charged particles [11,12]. Two quantities of $\mathrm{Pb}\left(\mathrm{NO}_{3}\right)_{2}$ (100 and $300 \mathrm{~g}$ ) were added to soil samples in order to study the impact of lead nitrate on the chemical and physical properties of soil and measure the removal efficiency of the washingelectrokinetic remediation technique. The EK process was enhanced with purging solutions, activated carbon, and mid compartment. Lead nitrate is soluble in water, having solubility of 565 $\mathrm{g} / \mathrm{l}$. Nitric acid $\left(\mathrm{HNO}_{3}\right)$ and sodium hydroxide $(\mathrm{NaOH})$ were used as purging solutions to control the $\mathrm{pH}$ value in the cathode and anode compartments, respectively. After several electrokinetic tests, activated carbon was used for preventing reverse electroosmotic flow occurring from anode to cathode. The physical and chemical properties of contaminant and purging solutions used in the compartments of electrokinetic cell are given in Table 1.

Table 1. Properties of contaminant and purging solutions.

\begin{tabular}{cccccc}
\hline $\begin{array}{c}\text { Chemical } \\
\text { compound }\end{array}$ & $\begin{array}{c}\text { Molar weight, } \\
\mathrm{g} / \mathrm{mol}\end{array}$ & $\begin{array}{c}\text { Density, } \\
\mathrm{g} / \mathrm{cm}^{3}\end{array}$ & Concentration & $\mathrm{pH}$ & $\begin{array}{c}\text { Electrical conductivity } \\
\mu \mathrm{S} / \mathrm{cm}\end{array}$ \\
\hline $\mathrm{Pb}\left(\mathrm{NO}_{3}\right)_{2}$ & 331.2 & 4.53 & $6.67,20 \mathrm{~g} / \mathrm{kg}$ & - & - \\
\hline $\mathrm{NaOH}$ & 39.99 & 2.13 & $0.1 \mathrm{~mol} / \mathrm{l}$ & 12.3 & 11150 \\
\hline $\mathrm{HNO}_{3}$ & 63.01 & 1.51 & $0.001 \mathrm{~mol} / \mathrm{l}$ & 2.5 & 664 \\
\hline
\end{tabular}

Preparation of contaminated soil samples

Two disturbed soil samples were placed in plastic containers and soaked with contamination solutions, covered with tightened covers and left for one month to ensure chemical reactions between the contaminant and solid skeletons of the soil. The soil sample of $15 \mathrm{~kg}$ weight was put in each container and covered with the contamination solution consisted from lead nitrate and distilled water. Two quantities (100 and $300 \mathrm{~g}$ ) of lead nitrate were mixed with 10 liters of distilled water. The distilled water was necessary for dissolution of $\mathrm{Pb}\left(\mathrm{NO}_{3}\right)_{2}$ and the final contaminant solution had to have sufficient volume to cover the soil sample and provide an adequate column (about $3 \mathrm{~cm}$ ) above the soil surface. In such a way, contaminant could penetrate deeper in the soil $[1,13]$. The soil samples used in this study were designated with the symbols given in Table 2.

Table 2. Designation of soil samples.

\begin{tabular}{ccc}
\hline Symbol & Definition & Concentration of lead nitrate in soil, $\mathrm{g} / \mathrm{kg}$ \\
\hline $\mathrm{M} 0$ & Intact soil sample & 0 \\
\hline $\mathrm{M} 1$ & Soil sample contaminated with $100 \mathrm{~g}$ of $\mathrm{Pb}\left(\mathrm{NO}_{3}\right)_{2}$ & 6.67 \\
\hline $\mathrm{M} 2$ & Soil sample contaminated with $300 \mathrm{~g}$ of $\mathrm{Pb}\left(\mathrm{NO}_{3}\right)_{2}$ & 20 \\
\hline
\end{tabular}

\section{Chemical and physical properties of soil samples}

The chemical and physical properties of intact and contaminated soil samples were measured according to ASTM standards [14]. The chemical properties of soil samples were important for analysis of chemical reactions between the contaminant and mineral composition of soil. The measured chemical properties were the contents of trioxide sulfate $\left(\mathrm{SO}_{3}\right)$, chloride ions $\left(\mathrm{Cl}^{-}\right)$, silicon dioxide $\left(\mathrm{SiO}_{2}\right)$, calcium oxide ( $\left.\mathrm{CaO}\right)$, organic matter (OMC), gypsum, total soluble salts (TSS), and pH value. As shown in Table 3, the results of chemical tests showed significant changes in contents of these components, resulting from the impacts of lead nitrate. 
Table 3. Chemical properties of tested soil samples.

\begin{tabular}{ccccccccc}
\hline \multirow{2}{*}{$\begin{array}{c}\text { Soil } \\
\text { sample }\end{array}$} & $\mathrm{SO}_{3}$ & $\mathrm{Cl}^{-}$ & $\mathrm{SiO}_{2}$ & $\mathrm{CaO}$ & $\mathrm{OMC}$ & Gypsum & TSS & \multirow{2}{*}{$\mathrm{pH}$} \\
\hline $\mathrm{M} 0$ & 0.036 & 0.5442 & 32.37 & 18.31 & 0.620 & 0.04 & 3.60 & 7.6 \\
\hline $\mathrm{M} 1$ & 0.221 & 0.2650 & 32.63 & 16.61 & 0.513 & 1.081 & 3.45 & 8.4 \\
\hline $\mathrm{M} 2$ & 0.346 & 0.3290 & 33.54 & 18.24 & 0.682 & 3.65 & 3.00 & 8.2 \\
\hline
\end{tabular}

The physical properties of soil samples listed in Table 4 involve the particle-size distribution, Atterberg's limits (LL and PL), specific gravity $(G S)$, maximum dry density $\left(\rho_{\text {dmax }}\right)$, optimum moisture content $\left(\omega_{\text {opt }}\right)$, and permeability of soil $(k)$. Also, the results demonstrated that presence of lead in soil samples tended to increase the percentage of particles that had size higher than $0.005 \mathrm{~mm}$ [1]. $\mathrm{CaCO}_{3}$ and $\mathrm{OMC}$ were the main compounds in the cementation between the particles of soil and are responsible for both, the sticking and stability of soil particles [15]. The lead has a greater adsorption ability on the surfaces of clay particles than other HMs, and formation of cation bridges among the particles of clayey soil resulted in increased stability of aggregate matrix.

Table 4. Physical properties of tested soil samples.

\begin{tabular}{|c|c|c|c|c|c|c|c|c|c|}
\hline \multirow{2}{*}{ Soil sample } & \multicolumn{3}{|c|}{ Content, \% } & \multirow{2}{*}{ LL, \% } & \multirow{2}{*}{$P L, \%$} & \multirow{2}{*}{ GS } & \multirow{2}{*}{$\begin{array}{l}\rho_{\text {dmax }} / \\
\mathrm{g} \mathrm{cm}^{-3}\end{array}$} & \multirow{2}{*}{$\begin{array}{c}\omega_{\text {opt }} / \\
\%\end{array}$} & \multirow{2}{*}{$\begin{array}{l}k \times 10^{-8} / \\
\mathrm{cm} \mathrm{sec}\end{array}$} \\
\hline & Sand & Silt & Clay & & & & & & \\
\hline $\mathrm{MO}$ & 0.020 & 25.98 & 74 & 55 & 27 & 2.74 & 1.678 & 21.6 & 3.22 \\
\hline M1 & 0.102 & 29.898 & 70 & 45 & 26 & 2.78 & 1.720 & 18.5 & 2.60 \\
\hline M2 & 0.273 & 43.373 & 56 & 43 & 21 & 2.83 & 1.760 & 17.0 & 1.86 \\
\hline
\end{tabular}

\section{Washing-enhanced electrokinetic remediation technique}

Electrokinetic remediation technology has great capability for treatment of low permeability soils contaminated with HMs and/or organic compounds [16]. Several studies showed that using water as an electrolyte is not effective to give high removal percentage, especially when the soil is contaminated with more than one type of contaminant. The EK technique, however, can be improved by different ways, such as increasing of treatment duration, increasing electric potential gradient, and using solvents or surfactants. It has also been found that the use of purging solutions is the most promising strategy for obtaining high removal efficiency [17]. The selection of enhancing agent depends on the type and concentration of contaminant and the type of soil.

Soil washing is one of technologies that has been used in remediation of contaminated soils, and is based on isolating and extracting the most contaminated fraction of the soil. In the soil washing process, several extracting fluids containing a chemical reagent (acid/base, surfactant, chelating agent, salt, or redox agent) is used to transfer metals from the soil into an aqueous solution. Soil washing can be used alone or linked with other treatment techniques. In this study, the soil washing was linked with the EK technique to enhance the removal efficiency of contaminant from the soil. The components and dimension of the EK test set up is shown in Figure 1. In the present study, the EK technique was enhanced by four ways. The first was installing of the mid-compartment to reduce the travel path required for exit of the contaminant particles from the soil. The second way is use of the activated carbon (AC) to keep the flow from anode to cathode and prevent reverse electroosmotic flow. The AC compartment is $5 \mathrm{~cm}$ in length, $10 \mathrm{~cm}$ in width and $10 \mathrm{~cm}$ in height. The third way was use of purging solution $\left(0.001 \mathrm{M} \mathrm{HNO}_{3}\right.$ in anode compartment put at initial state and followed by 
addition of $0.1 \mathrm{M} \mathrm{NaOH}$ and $0.001 \mathrm{M} \mathrm{HNO}_{3}$ in mid and cathode compartments, respectively). The fourth way of enhancement was utilization of the washing process.

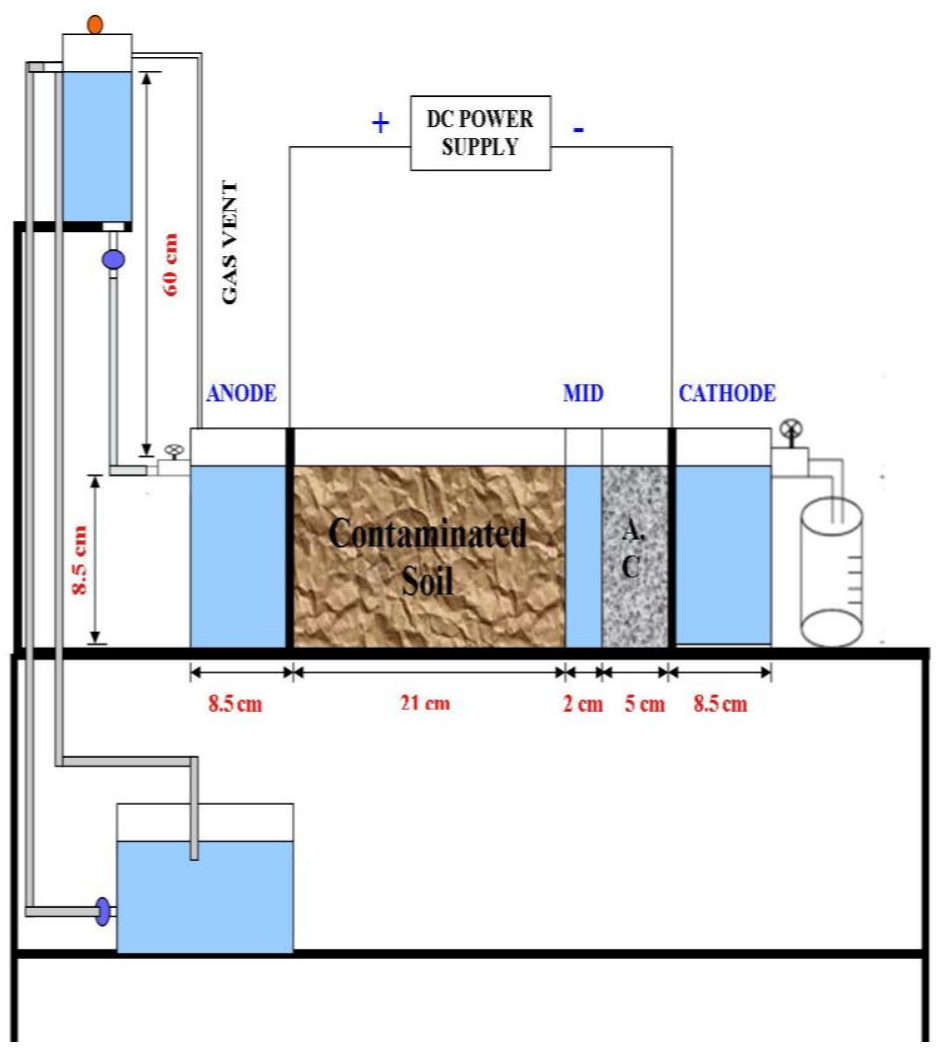

Figure 1. Schematic diagram of the electrokinetictest setup.

The major components of the system were power supply, pump station, and electrokinetic rectangular cell of dimensions $50 \mathrm{~cm}$ in length, $10 \mathrm{~cm}$ in width and $10 \mathrm{~cm}$ in height. The EK cell consisted of five compartments, for the soil sample, for the activated carbon, the mid compartment between soil and AC and two others for electrodes (anode and cathode). Each electrode compartment comprised a valve to manage the flow into the cell, a graphite electrode, filter paper and porous stone. The filter paper and porous stone were used to prevent soil particles from entrance into anode or cathode reservoirs. Gas vent tubes were provided in electrode compartments to release gases resulting from the electrolysis reactions and collect any liquid that was removed with the gases. A pH meter was used to measure changes in $\mathrm{pH}$ of the solution in the cathode, mid, and anode compartments and soil after remediation. The effluent from cathode compartment was collected to determine the accumulated volume of electroosmotic flow (EOF). The size, shape, and arrangement of electrodes and the distance between them affect also the removal efficiency. Only few researches have been conducted to select the optimum values for these parameters. The dimensions of electrodes used in the present study were $2 \mathrm{~cm}$ in thickness $\times$ $10 \mathrm{~cm}$ in width and $10.5 \mathrm{~cm}$ in height. Also, the voltage gradient through the soil sample will affect the movement of ions between opposite charged electrodes and the transport of charge by electroosmosis. A number of studies reported the voltage gradient in the range of $1-3 \mathrm{VDC} / \mathrm{cm}$ $[18,19]$. The choice of the most suitable voltage gradient relies on soil properties and contamination type, where soils of high electrical conductivity need more charge than soils of low electrical conductivity. Increase of the voltage gradient will increase transport rates, i.e. ionic migration and electroosmosis rates. At the other side, increase of the voltage gradient results in increase of the electric current, the cost of the process, and the produced heat. Therefore, the voltage gradient used in this study was set to $1.3 \mathrm{VDC} / \mathrm{cm}$. 


\section{Testing procedure}

The testing procedure can be described by the following steps:

1) preparing the EK cell (electrodes, purging solutions,a device used to control the hydraulic gradient).

2) Preparing the contaminated soil sample in the EK cell according to the field unit weight and natural moisture content. In front of the electrodes, the filter paper and porous stone were placed.

3) The electrodes compartments were filled with purging solutions. The anode reservoir was filled with $0.001 \mathrm{M} \mathrm{HNO}_{3}$ at the beginning of test, and then $0.1 \mathrm{M} \mathrm{NaOH}$ was added to maintain the $\mathrm{pH}$ higher than 2. The cathode and mid reservoirs were filled with $0.001 \mathrm{M} \mathrm{HNO}_{3}$ from the beginning of the experiment.

4) The graphite electrodes (anode and cathode) were linked to the power supply with a voltage gradient equal to $1.3 \mathrm{VDC} / \mathrm{cm}$.

5) The electric current, the volume of electroosmosis flow (EOF) and pH in the anode, mid, and cathode compartments were measured every hour during the testing period.

6) The test was stopped when the electrical current became constant or no change in EOF was observed.

7) At the end of each test, the soil specimen and AC are extruded from the cell by hands. The soil specimen was sectioned into five parts and each part was weighed and subsequently preserved in a glass container. For each soil section, pH was measured according to ASTM (D4972) and the residual concentration of lead was measured using AAS.

\section{Results and discussion}

The results of EK experiments measured with time involve: (1) the variation of electric current; (2) the rate of EOF; (3) pH values determined in compartments and soil sample, and (4) the lead content in the remediated soil samples.

\section{Electrical current}

The electrical current in the soil sample M2 was equal to zero at the first 30 hours of the EK test, then started to increase steadily, reached its maximum value and then decreased until a constant value was reached. For the soil sample M1, however, the electric current rose rapidly in the first hour of testing, reached its maximum and then continued steadily to the end of test. Increasing the concentration of ionic species in each experiment caused rising of the electrical current due to generation of $\mathrm{H}^{+}$and $\mathrm{OH}^{-}$ions at anode and cathode respectively. Increasing the mobility of soil solids due to the presence of ions causes rising of the electrical current produced during treatment process. The migration of these ions towards the electrodes during the treatment reduces the electric current $[9,20,21]$. Generally, the values of electrical current reached a peak value because dissolved salts that are connected with dry soil particles increased the quantity of ions in the pore solution $[13,20]$. The time required to get a stable current or reach the maximum value was variable and depended on migration rates of ions from solution to the soil column [23]. The profiles of electrical current vs. time are shown in Figure 2. 


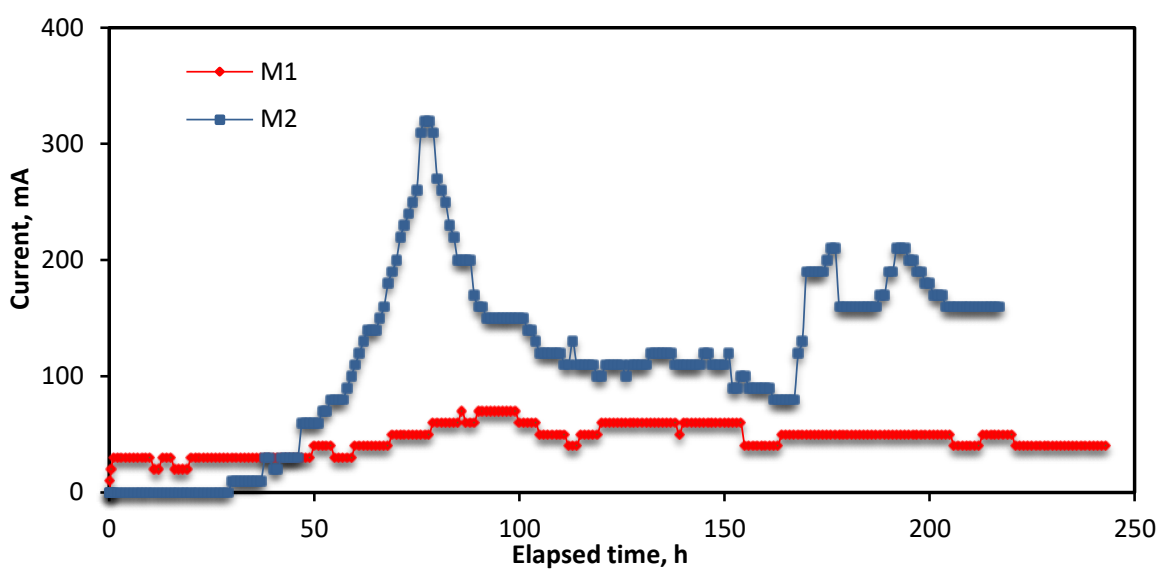

Figure 2. Variation of electrical current with time.

pH value

The values of $\mathrm{pH}$ measured in anode, mid, and cathode compartments during the period of testing and their variations with time are shown in Figure 3.
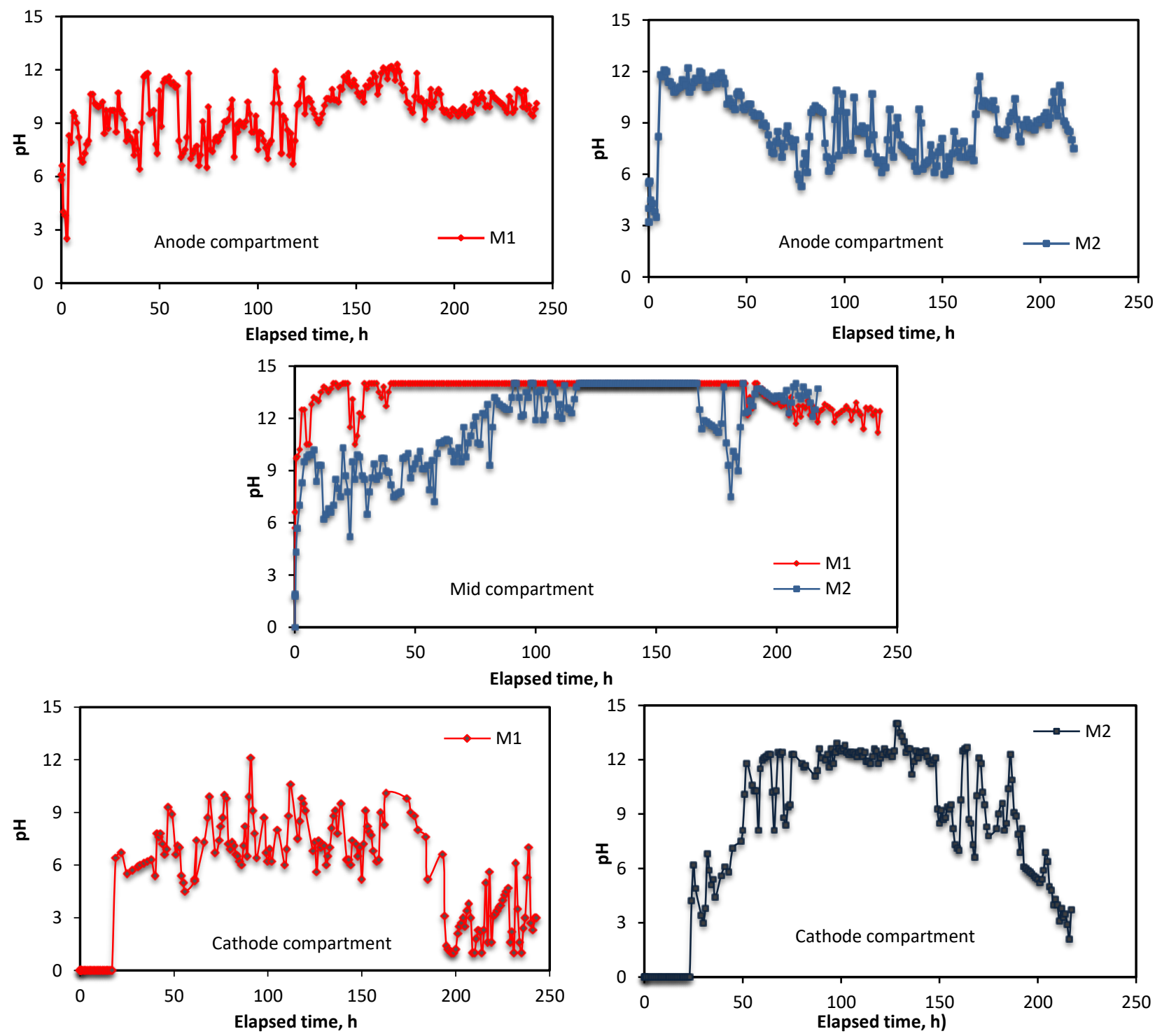

Figure 3. Variation of $\mathrm{pH}$ value of electrolyte solutions at three different compartments with time. 
Application of voltage gradient to the soil specimen that produced low DC current leads to the production of hydrogen and hydroxyl ions at electrodes. Consequently, an acidic medium at the anode and alkaline medium at the cathode were generated [24,25]. When $\mathrm{pH}$ reached the value about 2, $\mathrm{NaOH}$ was added to the solution in the anode compartment, so the value of $\mathrm{pH}$ increased. The values of $\mathrm{pH}$ in the mid compartment were inversely proportional to the concentration of contaminant in the soil. $\mathrm{pH}$ value in the mid compartment depended on the quantity of accumulated salts which was higher in the soil sample M2 than M1. Increasing the sediment of salts in the compartment led to the lowering of the $\mathrm{pH}$ value.

In general, the $\mathrm{pH}$ value at anode during the test should have decreased, but in the present study, the value of $\mathrm{pH}$ sometimes increased and oscillated between 6-12, what may be attributed to the applied hydraulic gradient (washing process). In the cathode compartment, the value of $\mathrm{pH}$ was equal to zero at the beginning of testing what was due to the effect of $A C$ which prevented the rapid change of $\mathrm{pH}$ value. After that, $\mathrm{pH}$ value began to increase and reached its maximum value due to the generation of hydroxide ions $\left(\mathrm{OH}^{-}\right)$. The increase of electroosmotic flow towards the cathode led to lowering of $\mathrm{pH}$ value near the cathode because of the opposite migration of ions $[26,27]$.

The lowering of $\mathrm{pH}$ value at the anode and rising at the cathode were accompanied by propagation of an acid front into the soil pores from the anode and a base front from the cathode. This process can significantly affect the soil zeta potential drop, as well as the solubility, ionic state and charge, and level of adsorption of the contaminant [28]. The variation of $\mathrm{pH}$ value of soil along the distance from anode to cathode is shown in Figure 4.

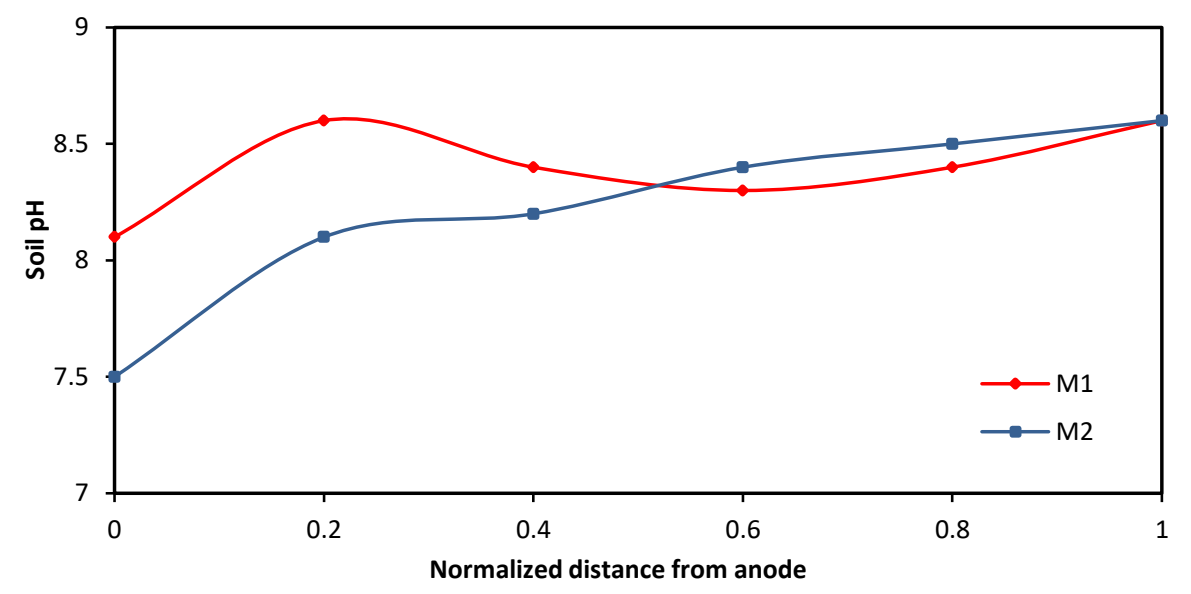

Figure 4. Profile of $\mathrm{pH}$ value of tested soil samples.

\section{Electroosmosis flow (EOF)}

Accumulative volumes of effluent from soil samples $\mathrm{M} 1$ and $\mathrm{M} 2$ are shown in Figure 5 . According to the electroosmotic phenomenon, the water carries lead nitrate from anode to cathode compartment. The high concentration of lead nitrate may lead to the reverse flow from cathode to anode compartment. Also, the electroosmotic flow can be reversed, what occurs when the charge of soil surface is converted from negative to positive. The surface charge depends on $\mathrm{pH}$ and ionic strength and so, the high concentration of lead nitrate leads to increase of ionic strength that influenced the surface charge and zeta potential. Lowering the $\mathrm{pH}$ value of the soil causes alteration of the net surface charge of soil from negative to positive, what is due to the sorption of hydrogen ions on the surface of soil particles. In the soil with a positive surface charge, the direction of electroosmotic flow changed from the cathode to the anode, and so it is important to keep the negative charge of the soil surface to avoid the reversed EOF. Also, the $\mathrm{pH}$ value of the soil should 
be maintained low enough to keep all contaminants in the dissolved phase $[28,29]$. The results of tests demonstrated that increase of the concentration of lead nitrate in the soil, increased the rate of EOF. This leads to increase of the ionic migration due to rise of the produced electrical current. Also, it is important to notice that EOF started 80 hours after the beginning of the experiment, what is due to low solubility of lead nitrate in water.

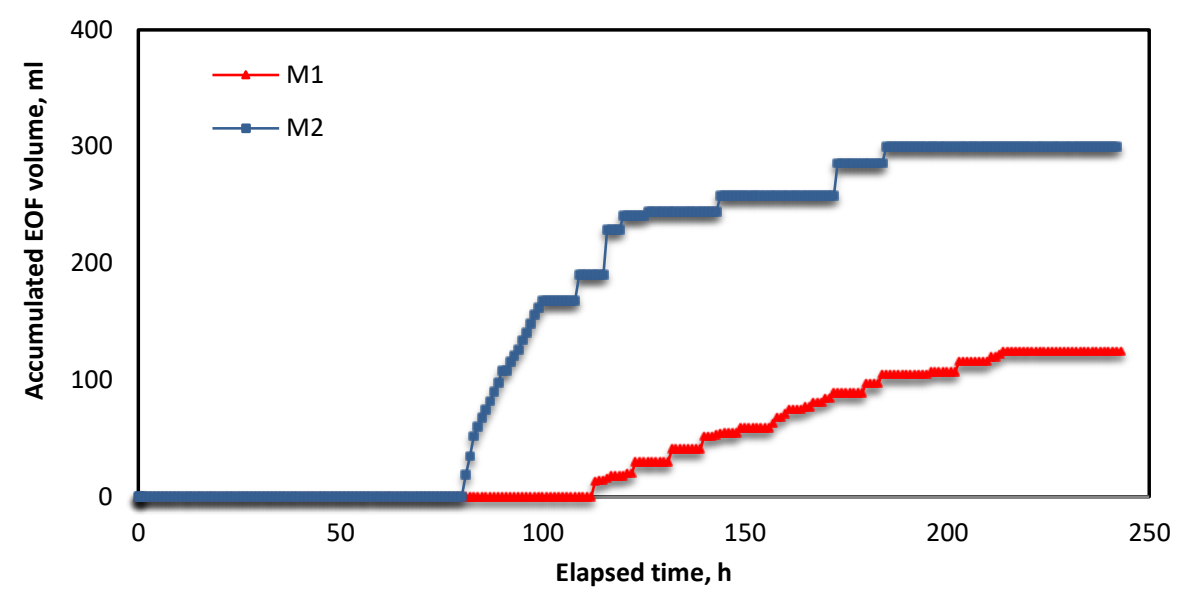

Figure 5. Accumulative volume of EOF in cathode compartment versus time

\section{Removal efficiency}

The residual concentrations of lead in the soil were measured using atomic absorption spectroscopy (AAS) device. The initial concentration of lead in the soil is calculated by Eq. (1):

$$
c_{\mathrm{Pb}} / \%=\frac{\text { atomic mass of lead } \times \text { used quantity }}{\text { atomic mass of lead nitrate }} 100
$$

The initial concentration of lead in the soil samples M1 and M2 were found equal to 4.17 and $12.512 \mathrm{~g} / \mathrm{kg}$, respectively. The removal efficiency is obtained by Eq. (2).

$$
\mathrm{ER}=\frac{c_{\mathrm{i}} / c_{\mathrm{f}}}{c_{\mathrm{i}}}
$$

In Eq. (2), ER is the the removal efficiency of lead from soil, while $C_{\mathrm{i}}$ and $C_{\mathrm{f}}$ are initial and final concentration of lead in the soil $(\mathrm{g} / \mathrm{kg})$. The removal efficiency of lead from soil samples $\mathrm{M} 1$ and $\mathrm{M} 2$ was determined as 12.4 and $21 \%$, respectively. Figure 6 shows the residual concentrations of lead in the soil after EK remediation.

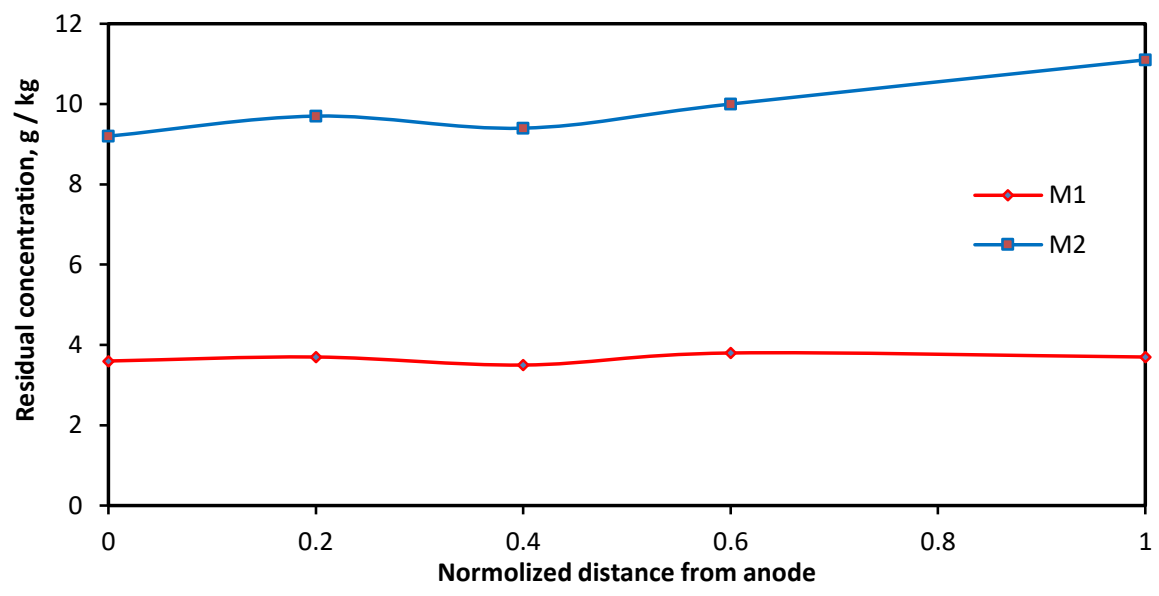

Figure 6. Variation of the residual concentration of lead in soil sample with distance 


\section{Conclusions}

The lead nitrate as a soil contaminant has diverse impacts on the chemical and physical characteristics of tested soil samples. The impacts of contamination depend on the concentration and type of contaminant, as well as the type of soil, where geotechnical properties of soil are highly influenced with increasing the concentration of lead nitrate in the soil. From the results of this study, the following conclusions can be drawn out:

1) The electrokinetic method is very effective technique to remediate low permeability soils.

2) The $\mathrm{pH}$ value of soil increased in the soil specimen when moving towards the cathode compartment.

3) The volume of EOF increased with increasing the concentration of lead in the soil.

4) The removal efficiency of lead from soil samples $M 1$ and $M 2$ is 12.4 and $21 \%$, respectively. The low removal efficiency can be attributed to the high molar weight of lead nitrate which prevents moving and transportation of contaminant particles in the EK process. The extraction efficiency can be improved by increased the value of voltage gradient or by using another effective purging solution to remove lead from the contaminated soil.

5) Using of activated carbon is very effective to prevent reverse EOF. The ability of activated carbon to adsorb a contaminant increases with increased concentration of contaminant in the soil.

6) Using the mid compartment to enhance the EK technique is very useful in shortening the exiting path of contaminant particles from the soil sample.

For the concentration of lead in soil increased over $6.67 \mathrm{~g} / \mathrm{kg}$, the voltage gradient must be kept less than $1.3 \mathrm{VDC} / \mathrm{cm}$ to avoid increasing temperature of EK cell what may cause a damage. Also, when the temperature exceeds $55^{\circ} \mathrm{C}$ in the cathode compartment, production of gases is increased, what can be poisonous and have detrimental effects to the human health.

\section{References}

[1] M. O. Karkush, A. T. Zaboon, H. M.Hussien, Coupled Phenomena in Environmental Geotechnics, Taylor \& Francis Group, London (2013) 599-607.

[2] M. K. Uddin, Chemical Engineering Journal 308 (2017) 438-462.

[3] S. O. N. G. Yue, A. Benamar, S. Mezazigh, W. A. N. G. Huaqing, Pedosphere 280(1) (2018) 35-43.

[4] S. Chinthamreddy, Doctoral dissertation (1999).

[5] K. R. Reddy, S. Chinthamreddy, Journal of Geotechnical and Geoenvironmental Engineering 129(3) (2003) 263-277.

[6] S. S. Kim, J. H. Kim, S. J. Han, Journal of Hazardous Materials 118(1-3) (2005) 121-131.

[7] M. O.Karkush, T. A. Altaher, Proceedings of the $19^{\text {th }}$ International Conference on Soil Mechanics and Geotechnical Engineering, Seoul (2017) 3139-3142.

[8] M. A. Karim, Journal of Electrochemical Science and Engineering 4(4) (2014) 297-313.

[9] Z. Li, J.W. Yu, I. Neretnieks, Journal of Hazardous Materials 55(1-3) (1997) 295-304.

[10] P. E. Jensen, L. M. Ottosen, T. C. Harmon, Environmental Engineering Science 24(2) (2007) 234-244.

[11] A. Shehzad, A. H. Khan, Z. Rehman, International Journal of Advanced Structures and Geotechnical Engineering 4 (2015) 138-147.

[12] A. Chandrasekaran, R. Ravisankar, N. Harikrishnan, K. K. Satapathy, M. V. R. Prasad, K. V. Kanagasabapathy, Spectrochimica Acta Part A: Molecular and Biomolecular Spectroscopy 137 (2015) 589-600.

[13] K. R. Reddy, M. R. Karri, Land Contamination \& Reclamation 14(3) (2006) 685-698.

[14] Annual Book of ASTM Standards, Soil and Rock. ASTM, Philadelphia, PA (2003).

[15] R. F. Craig, Craig's soil mechanics. CRC Press (2004).

[16] K. R. Reddy, C. Cameselle, Electrochemical remediation technologies for polluted soils, sediments and groundwater. John Wiley \& Sons, 2009. 
[17] K. R. Reddy, Coupled Phenomena in Environmental Geotechnics, Taylor \& Francis Group, London (2013) 131-147.

[18] K. R. Reddy, K. Darko-Kagya, A. Z. Al-Hamdan, Water, Air, \& Soil Pollution 221(1-4) (2011) 35-44.

[19] C. Cameselle, K. R. Reddy, Electrochimica Acta 86 (2012) 10-22.

[20] R. E. Saichek, K. R. Reddy, Critical Reviews in Environmental Science and Technology 35(2) (2005) 115-192.

[21] L. Rajić, B. Dalmacija, S. U. Perović, M. Bokorov, International Journal of Electrochemical Science 7 (2012) 58-67.

[22] G. Dermont, M. Bergeron, G. Mercier, M. Richer-Laflèche, Journal of Hazardous Materials 152(1) (2008) 1-31.

[23] D. M. Zhou, C. F.Deng, L.Cang, Chemosphere 56(3) (2004) 265-273.

[24] J. S. Wong, R. E. Hicks, R. F. Probstein, Journal of Hazardous Materials 55(1-3) (1997) 61-79.

[25] A. Giannis, E. Gidarakos, Journal of Hazardous Materials 123(1-3) (2005) 165-175.

[26] M. Saeedi, A. Jamshidi, N. Shariatmadri, A. Falamaki, International Journal of Environmental Research 3(4) (2009) 629-636.

[27] K. R. Reddy, R. E. Saichek, K. Maturi, P. Ala, Indian Geotechnical Journal 32(2) (2002) 258-288.

[28] J. Virkutyte, M. Sillanpää, P. Latostenmaa, Science of the Total Environment 289(1-3) (2002) 97-121.

[29] D. H. Kim, B. G. Ryu, S. W. Park, C. I. Seo, K. Baek, Journal of Hazardous Materials 165(1-3) (2009) 501-505.

(C2019 by the authors; licensee IAPC, Zagreb, Croatia. This article is an open-access article distributed under the terms and conditions of the Creative Commons Attribution license (http://creativecommons.org/licenses/by/4.0/) 